https://doi.org/10.30910/turkjans.471122

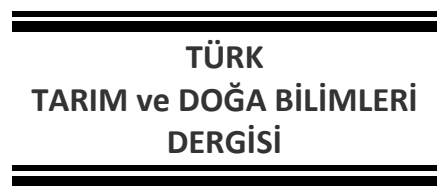

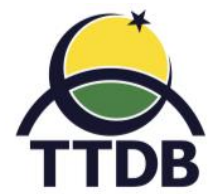

www.dergipark.gov.tr/turkjans

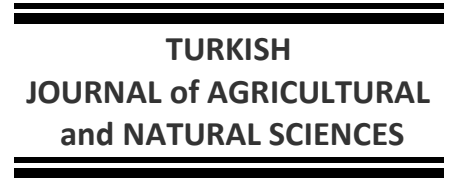

Araştırma Makalesi

\title{
Ekmeklik Buğday (Triticum aestivum L.) Genotiplerinde Farklı Gelişme Dönemlerinde Oluşan Kuraklığın Bazı Fizyolojik Karakterlere Etkisi ${ }^{a}$
}

\author{
İrfan ÖZTÜRK ${ }^{1 *}$, Kayıhan Z. KORKUT ${ }^{2}$ \\ ${ }^{1}$ Trakya Tarımsal Araştırma Enstitüsü, Edirne \\ ${ }^{2}$ Namık Kemal Üniversitesi, Ziraat Fakültesi, Tarla Bitkileri Bölümü, Tekirdağ \\ *Sorumlu yazar: irfan.ozturk@tarim.gov.tr
}

Geliş Tarihi: 08.12.2017

Düzeltme Geliş Tarihi: 29.07.2018

Kabul Tarihi: 01.08.2018

\section{Özet}

Ekmeklik buğdayda kuraklık verim ve kaliteyi doğrudan etkileyen önemli bir abiyotik stres faktörüdür. Araştırmada bazı ekmeklik buğday genotiplerinin farklı kuraklık seviyelerinde verim ve bazı fizyolojik karakterler arasındaki ilişkiler incelenmiştir. Bölünmüş parseller deneme desenine göre 2008-2009 ve 2009-2010 yıllarında yürütülen ve 15 genotipin materyal olarak kullanıldığı deneme 3 tekrarlamalı olarak kurulmuştur. Denemede ana parsellerde kuraklık uygulamaları, alt parsellerde genotipler yer almıştır. Araştırmada; tane verimi ile üç farklı gelişme döneminde bitki örtüsü sıcaklığı ve bayrak yaprakta klorofil miktarı ölçülmüştür. Ayrıca başaklanma ve olgunlaşma gün sayıları, tane dolum süresi ve mumsuluk oranları ile bu karakterler arasındaki ilişkiler incelenmiştir. Araştırmada genotipler ve uygulamalar arasında önemli farklılıklar tespit edilmiştir. En düşük bitki örtüsü sıcaklığı Kate A-1 de görülürken en yüksek sıcaklık Golia çeşidinde ölçülmüştür. En düşük sıcaklık değerleri gebeleşme $\left(17.21^{\circ} \mathrm{C}\right)$, başaklanma $\left(19.96^{\circ} \mathrm{C}\right)$ ve tane dolum dönemlerinde $\left(20.11^{\circ} \mathrm{C}\right)$ kuraklık uygulanmayan parsellerde ölçülmüştür. En yüksek sıcaklıklar ise başaklanma ve tane dolum dönemlerinde tam kuraklık uygulamalarında belirlenmiştir. Kanopi sıcaklığının tane verimini olumsuz yönde etkilemiş olup kanopi sıcaklığı ile tane verimi arasında korelasyon katsayıları başaklanma öncesi $r=-0.779$, başaklanma dönemi $r=-0.793$ ve tane dolum dönemi $r=-0.924$ * olarak belirlenmiştir. Kuraklık stresi klorofil miktarını üç bitki gelişme döneminde de düşürmüş olup en yüksek klorofil miktarı kuraklık stresi uygulanmayan parselde belirlenmiştir. Genotiplerde başaklanma döneminde en yüksek klorofil miktarı ÖVD2/27-07 ve tane dolum döneminde EBVD24-07 hatlarında ölçülmüştür. Tane verimi ile bayrak yaprak klorofil içeriği arasında ilişki başaklanma öncesi $r=0.499$, başaklanma dönemi $r=0.498$ ve tane dolum dönemi $r=0.954$ * olarak belirlenmiştir. Araştırma sonucu kanopi sıcaklığı ve klorofil kapsamının farklı kuraklık stresi altında verim için seleksiyon kriteri olarak kullanılabileceğini göstermiştir.

Anahtar kelimeler: Ekmeklik buğday, kuraklık stresi, genotip, klorofil, kanopi sıcaklığı.

\section{Effect of Drought Stress Condition on Different Plant Growth Stages on Some Physiological Traits in Bread Wheat (Triticun aestivum L.) Genotypes}

\begin{abstract}
Drought is the mainly abiotic stress factor in wheat affecting yield and quality. In this research it was investigated yield and some physiological traits under various drought stress condition and the relationships between physiological characters in some bread wheat genotypes. This research was carried out in 2008-2009 and 2009-2010 cycle during 2 growing seasons with totally 15 bread wheat genotypes in split block design with 3 replicated. Drought applications were main plot and genotypes were sub-plot. In this research, yield and some physiological traits such as canopy temperature and chlorophyll content were investigated at various three plant growth stages. Also, days of heading and maturating, grain filling period, glaucousity and among these traits were investigated. Combined analysis of variance indicated significant differences among genotypes and treatments. The lowest canopy temperature was measured from Kate A-1 and the highest temperature from Golia. Canopy temperature negatively affected grain yield and correlation coefficient between yield and canopy temperature
\end{abstract}


was at booting $(r=-0.779)$, heading stage $(r=-0.793)$ and grain filling stage $\left(r=-0.924^{*}\right)$ under non-stress conditions. Highest canopy temperature was determined at heading and grain filling stage under fully drought treatment. Drought stress negatively affected and reduced leaf chlorophyll content at three development stages. The highest leaf chlorophyll content was determined under non-stress treatment. The highest chlorophyll content was measured in ÖVD2/27-07 at heading stage and in EBVD24-07 at grain filling stage. Determined correlation coefficient between grain yield and chlorophyll content were at booting $r=0.499$, heading stage $r=$ 0.498 , and grain filling stage $r=0.954^{*}$. The results of the study showed that canopy temperature and chlorophyll content could be used as selection physiological parameters for yield under various drought stress conditions.

Key Words: Bread wheat, drought stress, genotype, canopy temperature, chlorophyll.

\section{Giriş}

Kuraklık, bitki verimliliğini sınırlayan önemli abiyotik stres faktörleri arasında yer almaktadır. Akdeniz bölgesi iklimi özellikle düzensiz ve önceden tahmin edilemeyen yağış rejimi ile karakterize edilmektedir (Loss et al. 1994). Kuraklığa toleranslılığı kontrol eden fizyolojik ve genetik adaptasyon mekanizmaların anlaşılması bitki biyolojisinde çok önemli bir husustur. Su stresinin olduğu koşullarda kök gelişimi kuraklığa toleransa katkı yapan önemli bir husustur (Shimazaki et al., 2005). Kuraklık stresi altında ölçülen kanopi sıcaklığı bitki bünyesindeki su durumunu belirtmektedir. Kuraklık stresi olmayan normal koşullarda genotipler arasındaki kanopi sıcaklığında çok az fark olurken, kuraklık stresinin yaşandığı koşullarda genotiplerde kanopi sıcaklıkları farkında artış olmaktadır. Stres koşullarında kanopi sıcaklığı ile verim arasında olumsuz ilişki bulunmaktadır (Blum, 2000). Kuraklık stresi altında daha düşük kanopi sıcaklığına sahip genotipler kurağa daha toleranslı olup kanopi sıcaklığı kuraklık ve su stresine karşı bir seleksiyon özelliği olarak kullanılabilmektedir (Blum ve ark., 1989). Tarla koşullarında buğdayda bitkiler sıklıkla aynı anda kuraklık ve yüksek sıcaklık stresine maruz kalmaktadır. Bu iki stres faktörü bitki dokularında su açığı yaratabilir ve bu da verimi etkileyebilir. Kuraklığı genellikle yüksek sıcaklıklar teşvik eder, bu da evapotranspirasyonu arttırır, bitkilerin fotosentez kapasitesini azaltır ve sonuçta ürün verimini düşürür (Reynolds ve Ortiz, 2010). Kanopi sıcaklığı buğdayda su stresinin belirlenmesi amacıyla kullanılmaktadır (Idso ve ark., 1981). Farklı seviyede kuraklık stresi altında kanopi sıcaklığı buğday çeşitlerinin performansı ile olumsuz ilişkide olduğu görülmektedir (Diaz ve ark., 1983). Kanopi sıcaklığı stoma iletkenliği, transpirasyon oranı, bitki suyu durumu, su kullanımı, yaprak alan indeksi ve ürün verimi gibi birçok fizyolojik faktörü belirlemek için kullanılabilir (Pask et al., 2012).

Bazı bitki türlerinde mumsuluğun \%5 ila \%30 arasında daha yüksek verim sağladığı görülmüştür (Clarke ve McCaig, 1982; Jefferson ve ark., 1989; Merah ve ark., 2000; Richards ve ark., 1986), ayrıca mumsuluk bitki kanopisinin serin olmasını sağlamaktadır (Jefferson ve ark., 1989; Richards ve ark., 1986). Mumsu yapıya sahip bitkilerin yaprakları kurak çevre koşullarında mumsuz olanlara göre daha uzun süre yeşil kalırlar. Kurak çevre koşullarında mumsu yapıya sahip bitkilerde kanopi sıcaklığı mumsuz olanlara göre 0.7 derece daha serin olmaktadır (Richards ve ark., 1986). Tane verimi çiçeklenme sonrası klorofil kaybıyla olumsuz, klorofil içeriği ile olumlu ilişkilidir (Reynolds ve ark., 1994). Bitkilerde klorofil kaybıyla ilgili fizyolojik göstergelerin tane doldurma süresince devam etmesi verim düşüşüyle ilişkilidir (Reynolds ve ark., 2001).

Trakya Bölgesinde iklim özelliklerinde değişkenlik özellikle sapa kalkma dönemi ile tane dolum dönemleri arasındaki yağışın miktar ve dağılımı buğdayda verimi etkileyen en önemli çevresel faktördür (Anonim 2014; Öztürk ve ark., 2018). Tane dolum dönemindeki yüksek sıcaklık bu dönemdeki yağışın miktar ve dağılımına bağlı olarak verim ve kaliteyi belirleyen önemli çevresel faktörlerdir. Araştırmada Trakya Bölgesinde üretimi yapılan çeşitlerin ve geliştirilen bazı ileri kademe genotiplerin farklı bitki gelişme döneminde uygulanan kuraklığa karşı tepkilerinin ve kuraklığa toleranslı genotiplerin belirlenmesi amacıyla yürütülmüştür. Ayrıca araştırmada incelenen ve kurağa dayanıklılık açısından önemli olan karakterler ıslah çalışmalarında seleksiyon kriteri olarak kullanılması da çalışmanın amaçlarındandır.

\section{Materyal ve Yöntem}

Araştırma, Trakya Tarımsal Araştırma Enstitüsü deneme tarlasında, 2008-2009 ve 20092010 yıllarında 2 yıl süreyle yürütülmüştür. Denemede 5 ana parsel yer almış olup, ana parselleri kuraklık uygulamaları, alt parselleri genotipler oluşturmuştur. Deneme toplam 15 ekmeklik buğday genotipi ile tesadüf bloklarında bölünmüş parseller deneme desenine göre 3 tekrarlamalı olarak kurulmuştur. Araştırmada; Kate A-1, Gelibolu, Pehlivan, Tekirdağ, Selimiye, Aldane, Bereket, Flamura-85 ve Golia çeşitleri ile 6 adet ileri kademe hat kullanılmıştır. Denemede parseller 6 sıralı ve alanı $6 \mathrm{~m}^{2}$ olarak düzenlenmiş ve metrekareye 500 tane tohum düşecek şekilde ekim makinesi ile yapılmıştır. 
Çizelge 1. Araştırmanın yürütüldüğü yerde ölçülen bazı iklim verileri.

\begin{tabular}{|c|c|c|c|c|c|c|}
\hline \multirow{2}{*}{ Aylar } & \multirow{2}{*}{ Yıllar } & \multirow{2}{*}{$\begin{array}{l}\text { Aylık Toplam } \\
\text { Yağış (mm) }\end{array}$} & \multirow{2}{*}{$\begin{array}{c}\text { Aylık } \\
\text { Nem (\%) }\end{array}$} & \multicolumn{3}{|c|}{ Sıcaklık $\left({ }^{\circ} \mathrm{C}\right)$} \\
\hline & & & & En Düşük & En Yüksek & Ortalama \\
\hline \multirow{2}{*}{ Ekim } & $2008-2009$ & 17.0 & 72.6 & 3.5 & 26.5 & 14.9 \\
\hline & $2009-2010$ & 112.6 & 82.3 & 2.9 & 28.9 & 15.1 \\
\hline \multirow{2}{*}{ Kasım } & $2008-2009$ & 29.2 & 77.8 & -2.0 & 18.3 & 15.3 \\
\hline & $2009-2010$ & 51.7 & 89.7 & -1.7 & 22.7 & 9.7 \\
\hline \multirow{2}{*}{ Aralık } & $2008-2009$ & 35.6 & 82.2 & -6.9 & 20.4 & 6.4 \\
\hline & $2009-2010$ & 93.4 & 89.7 & -2.1 & 19.6 & 7.3 \\
\hline \multirow{2}{*}{ Ocak } & $2008-2009$ & 48.6 & 87.8 & -11.2 & 17.5 & 6.5 \\
\hline & 2009-2010 & 59.6 & 85.2 & -16.3 & 20.3 & 2.5 \\
\hline \multirow{2}{*}{ Şubat } & $2008-2009$ & 83.2 & 81.3 & 0.1 & 13.5 & 5.2 \\
\hline & $2009-2010$ & 107.0 & 88.1 & -4.8 & 20.3 & 5.9 \\
\hline \multirow{2}{*}{ Mart } & $2008-2009$ & 44.1 & 77.5 & 3.0 & 17.9 & 7.8 \\
\hline & $2009-2010$ & 47.6 & 81.9 & -3.1 & 22.2 & 7.7 \\
\hline \multirow{2}{*}{ Nisan } & $2008-2009$ & 15.8 & 68.8 & -0.4 & 25.9 & 12.3 \\
\hline & $2009-2010$ & 17.8 & 76.0 & 0.9 & 24.9 & 12.7 \\
\hline \multirow{2}{*}{ Mayıs } & $2008-2009$ & 27.7 & 66.1 & 7.5 & 32.1 & 19.1 \\
\hline & $2009-2010$ & 16.0 & 68.6 & 3.3 & 33.6 & 18.1 \\
\hline \multirow{2}{*}{ Haziran } & $2008-2009$ & 25.9 & 62.5 & 9.3 & 36.4 & 22.6 \\
\hline & $2009-2010$ & 30.8 & 72.3 & 12.0 & 38.7 & 22.5 \\
\hline \multirow{3}{*}{$\begin{array}{l}\text { Ortalama/ } \\
\text { Toplam }\end{array}$} & $2008-2009$ & 327.1 & 75.2 & -11.2 & 36.4 & 12.2 \\
\hline & 2009-2010 & 536.5 & 81.5 & -16.3 & 38.7 & 11.3 \\
\hline & Ortalama & 431.8 & 78.4 & -16.3 & 38.7 & 11.8 \\
\hline
\end{tabular}

Kuraklık uygulanacak ana parsellere bitkiler sapa kalkma döneminden önce portatif seralar kurulmuştur. Bu seraların üzeri yağmurun düşmemesi için şeffaf naylon örtülerle açılır-kapanır sistem kurularak yağmurdan önce kapatılarak kuraklık stresi oluşturulmuştur. Araştırmada ana parsellerde yapılan uygulamalar; birinci uygulamada (KS1) Zadoks skalasına (Zadoks ve ark., 1974) göre GS31-51 dönemleri arasında kuraklık uygulanıp, bu dönemden sonra tane dolum döneminde günlük buharlaşma su miktarına göre bir defa sulama yapılmıştır. İkinci uygulamada (KS2) GS51-94 döneminde kuraklık uygulanmıştır. Bu uygulamada sapa kalkma ile başaklanma dönemleri arasında günlük buharlaşma su miktarına göre bir defa sulama yapılmıştır. Üçüncü uygulamada (KS3) kuraklık stresi uygulanmamış olup sapa kalkma, başaklanma ve tane dolum dönemlerinde günlük buharlaşma su miktarına göre 3 defa sulama yapılmıştır. Dördüncü uygulama (KS4; Doğal) doğal uygulama olup, beşinci uygulamada (KS5) GS31-94 dönemi arasında tam kuraklık uygulaması yapılmıştır.

Araştırmada infrared termometre ile bitki örtüsü sıcaklığı (Amani ve ark., 1996; Ayeneh ve ark., 2002; Fuchs ve ark., 1990; Reynolds ve ark., 2000) gebeleşme (GS45), başaklanma (GS60) ve tane dolum dönemi (GS75) olmak üzere üç farklı bitki gelişme döneminde ölçüm yapılmıştır. Genotiplerde bayrak yaprakta klorofil ölçümü SPAD 502 klorofilmetre (Babar ve ark., 2006a; Babar ve ark., 2006b; Fischer, 2007; Lopes ve Reynolds, 2010; Lopes ve Reynolds, 2012) ile bitkilerin gebeleşme (GS45) başaklanma (GS60) ve tane dolum dönemi (GS75) olmak üzere üç farklı gelişme döneminde ölçüm yapılmıştır. Ayrıca tane verimi ile fizyolojik parametreler ve başaklanma ve olgunlaşma gün sayıları, tane dolum süresi ve mumsuluk oranları (19) ile bu karakterler arasındaki ilişkiler incelenmiştir. Araştırmada elde edilen verilerin istatistiki değerlendirilmesi ve ortalamalar en küçük önemli fark (AÖF) testi ile karşılaştırılmıştır (Gomez ve Gomez, 1984; Kalaycı, 2005).

\section{Bulgular ve Tartışma}

Araştırmada genotiplerde incelenen tane verimi ile başaklanma öncesi (CTB), başaklanma (CTH) ve tane dolum dönemlerinde (CTGF) her parselde ölçüm yapılan kanopi sıcaklığı değerlerine ait varyans analiz sonuçları Çizelge 2 'de verilmiştir. Araştırmada tane verimi yönünden genotipler ve uygulama konuları arasındaki farklılık ile bunların arasındaki etkileşim $p<0.01$ seviyesinde çok önemli bulunmuştur. Araştırmada kanopi sıcaklığı bitki gelişmesinin başaklanma öncesi, başaklanma ve tane dolum dönemleri olmak üzere üç farklı bitki gelişme döneminde ölçülmüş ve ölçüm yapılan üç bitki gelişme döneminde bütün kuraklık uygulamalarında kurak koşullarda bitki örtüsü sıcaklığında artış olmuştur (Çizelge 4). 
Çizelge 2. Araştırmada incelenen verim ve kanopi sıcaklığı değerlerine ait varyans analizi sonuçları.

\begin{tabular}{lccccccccc}
\hline \multirow{2}{*}{ Kaynaklar } & \multirow{2}{*}{ SD } & \multicolumn{2}{c}{ Verim } & \multicolumn{2}{c}{ CTB } & \multicolumn{3}{c}{ CTH } & \multicolumn{2}{c}{ CTGF } \\
\cline { 2 - 10 } & & HKO & F & HKO & F & HKO & F & HKO & F \\
\hline YIl & 1 & 138973 & $77.2^{* *}$ & 5.1 & $9.7^{* *}$ & 203.9 & $198.9^{* *}$ & 653.7 & $694.9^{* *}$ \\
Tekerrür[yIl] & 4 & 3605.3 & 2.0 & 19.2 & 36.3 & 27.8 & 27.1 & 2.1 & 2.2 \\
Genotip & 14 & 132627 & $73.7^{* *}$ & 4.2 & $8.0^{* *}$ & 2.9 & $2.9^{* *}$ & 23.0 & $24.5^{* *}$ \\
YII*Genotip & 14 & 16164.2 & $8.9^{* *}$ & 1.7 & $3.3^{* *}$ & 1.3 & 1.3 & 5.1 & $5.4^{* *}$ \\
Hata & 56 & 1800 & 0.9 & 0.5 & 0.4 & 1.0 & 0.8 & 0.9 & 0.8 \\
Uygulama & 4 & 1120796 & $600.4^{* *}$ & 270.6 & $178.7^{* *}$ & 1536.1 & $1192.7^{* *}$ & 662.5 & $603.3^{* *}$ \\
YII*Uygulama & 4 & 72058.2 & $38.6^{* *}$ & 21.4 & $14.1^{* *}$ & 26.5 & $20.6^{* *}$ & 40.2 & $36.6^{* *}$ \\
Genotip*Uygulama & 56 & 4633.5 & $2.5^{* *}$ & 1.0 & 0.6 & 1.0 & 0.8 & 1.5 & $1.4^{*}$ \\
YII*Genotip*Uygulama & 56 & 3436.3 & $1.8^{* *}$ & 0.8 & 0.6 & 1.4 & 1.1 & 1.6 & $1.5^{*}$ \\
\hline
\end{tabular}

Araştırmada genotiplerde başaklanma öncesi ( $\mathrm{CHB})$, başaklanma $(\mathrm{CHH})$ ve tane dolum dönemlerinde (CHGF) bayrak yaprakta ölçüm yapılan klorofil kapsamı ile mumsuluk değerlerine ait varyans analizi sonuçları Çizelge 3'te verilmiştir. Araştırmada mumsuluk yönünden genotipler ve uygulama konuları arasındaki farklılık ile bunların arasındaki etkileşim $p<0.01$ seviyesinde çok önemli bulunmuştur. Genotiplerdeki klorofil kapsamına göre ise başaklanma öncesinde (CHB) önemli bir farklılık görülmezken, başaklanma $(\mathrm{CHH})$ ve tane dolum dönemlerinde (CHGF) bayrak yaprakta ölçüm yapılan klorofil kapsamı yönünden genotipler ve uygulama konuları arasındaki farklılık ile bunların arasındaki etkileşim $\mathrm{p}<0.01$ seviyesinde çok önemli bulunmuştur (Çizelge 3).

Çizelge 3. Araştırmada incelenen mumsuluk ve klorofil kapsamına ait varyans analizi sonuçları.

\begin{tabular}{lcccccccccc}
\hline \multirow{2}{*}{ Kaynaklar } & \multirow{2}{*}{ SD } & \multicolumn{3}{c}{ MUM } & \multicolumn{2}{c}{ CHB } & \multicolumn{2}{c}{ CHH } & \multicolumn{2}{c}{ CHGF } \\
\cline { 3 - 10 } & & HKO & F & HKO & F & HKO & F & HKO & F \\
\hline YIl & 1 & 54.1 & $57.5^{* *}$ & 765.6 & $85.4^{* *}$ & 123.4 & $31.0^{* *}$ & 7358.5 & $1498.6^{* *}$ \\
Tekerrür[yIl] & 4 & 0.2 & 0.2 & 3.4 & 0.4 & 6.9 & 1.7 & 33.1 & 6.7 \\
Genotip & 14 & 172.8 & $183.6^{* *}$ & 103.9 & 11.6 & 97.6 & $24.6^{* *}$ & 201.4 & $41.0^{* *}$ \\
YI*Genotip & 14 & 6.7 & $7.2^{* *}$ & 17.9 & $2.0^{*}$ & 18.8 & $4.7^{* *}$ & 32.0 & $6.5^{* *}$ \\
Hata & 56 & 0.9 & 2.0 & 8.9 & 1.1 & 4.0 & 1.1 & 4.9 & 0.5 \\
Uygulama & 4 & 14.7 & $31.5^{* *}$ & 13.1 & 1.7 & 39.3 & $11.1^{* *}$ & 1022.4 & $105.7^{* *}$ \\
YII*Uygulama & 4 & 3.7 & $7.9^{* *}$ & 15.9 & 2.0 & 11.5 & $3.2^{*}$ & 570.7 & $59.0^{* *}$ \\
Genotip*Uygulama & 56 & 1.0 & $2.2^{* *}$ & 7.5 & 1.0 & 4.3 & 1.2 & 15.5 & $1.6^{* *}$ \\
YII*Genotip*Uygulama & 56 & 0.7 & $1.6^{*}$ & 6.9 & 1.0 & 3.8 & 1.1 & 11.2 & 1.2 \\
\hline
\end{tabular}

Araştırmada kuraklık uygulamaları genotiplerde tane verimini farklı oranlarda düşürmüştür. En yüksek verim Bereket çeşidinde (658.3 kg da-1) tespit edilirken kuraklık uygulamalarında beklenildiği gibi en yüksek verim $763.8 \mathrm{~kg} \mathrm{da}^{-1}$ ile kuraklık stresi uygulanmayan (KS3) koşullarda belirlenmiştir. Tam kuraklık uygulamasında (KS5) tane verimi \% 40.1 azalırken, sapa kalkma döneminde $\% 28.0$ (KS1) ve tane dolum döneminde ise \%26.2 (KS2) oranında azalma olmuştur. Ayrıca sapa kalkma dönemindeki kuraklığın tane dolum dönemindeki kuraklığa göre tane verimini daha fazla etkilediği belirlenmiştir.

Ortamdaki hava sıcaklığına göre bitki örtüsü sıcaklık farkı olarak ifade edilen kanopi sıcaklığının düşük olması genotiplerde kuraklık açısından önemli bir özellik olarak değerlendirilmektedir (Fischer, 2001). Araştırmada başaklanma öncesi dönemde yapılan ölçümde ortalama kanopi sıcaklığı $19.47{ }^{\circ} \mathrm{C}$ olmuştur. Bu dönemde en yüksek sıcaklık $21.65{ }^{\circ} \mathrm{C}$ ile başaklanma öncesi dönemde kuraklık uygulanan (KS1) parsellerde, en düşük sıcaklık ise 17.21 derece ile kuraklık stresi uygulanmayan (KS3) parsellerde ölçülmüştür. Başaklanma döneminden itibaren parsellerde kuraklık stresinin etkisi artmaya başlamış bu nedenle uygulamalar arasında kanopi sıcaklığı farkında artış olmuştur. Başaklanma döneminde yapılan ölçümde ise en yüksek sıcaklık $29.21{ }^{\circ} \mathrm{C}$ ile tam kuraklık uygulanan (KS5) ana parsellerde, en düşük sıcaklık ise $19.96{ }^{\circ} \mathrm{C}$ ile kuraklık stresi uygulanmayan (KS3) parsellere ölçülmüştür (Çizelge 4). Tane dolum döneminde ölçüm yapılan kanopi sıcaklığı önceki bitki gelişme dönemlerindeki sonuca paralel olarak en yüksek sıcaklık yine tam kuraklık uygulamalarında en düşük sıcaklık ise kuraklık stresi uygulanmayan koşullarda saptanmıştır.

Genotiplere göre ölçüm yapılan üç bitki gelişme döneminde de en düşük kanopi sıcaklığı Kate A-1 çeşidinde ölçülmüş olup bu çeşidin yüksek verim potansiyeline sahip olması kanopi sıcaklığı ile verim arasındaki ilişkiyi doğrulamıştır. Araştırmada 
mumsuluk oranı en yüksek olan BBVD7 hattı, Kate A-1 çeşidinden sonra düşük kanopi sıcaklığı ölçülen diğer bir genotip olmuştur. Genotiplerde yapraklarda mumsuluk oranının artışı kanopi sıcaklığını düşürmüştür. En yüksek kanopi sıcaklıkları ise Golia ve Tekirdağ çeşitlerinde ölçülmüştür (Çizelge 5). Her iki çeşidin mumsuz ve açık yaprak rengine sahip olmaları kanopi sıcaklığının yaprak rengi ve mumsuluk oranı ile ilişkisini göstermiştir.

Genotiplerde başaklanma öncesi, başaklanma ve tane dolum döneminde ölçüm yapılan kanopi sıcaklığı ölçüm yapıldığı andaki hava sıcaklığı sonuçlarına göre de değişim gösterdiği görülmüştür. Her üç ölçüm döneminde de beklenildiği gibi destek sulama ile kuraklık stresi uygulanmayan (KS3) parsellerde en düşük kanopi sıcaklığı ölçülmüştür. Ölçüm yapıldığı dönemde kuraklık stresi uygulamalarında ise kanopi sıcaklığında artış olmuştur. Kuraklık stresinin uygulanmadığı doğal koşullarda kanopi sıcaklığına göre genotipler arasındaki çok az fark olurken, kuraklık stresinin uygulandığı koşullarda genotiplerde kanopi sıcaklıkları farkında artış olmasından (Blum, 2000) dolayı araştırmada erken dönem ve doğal uygulamalarda verim ile kanopi sıcaklığı ve klorofil kapsamı arasında önemli ilişki belirlenmemiştir. Bu karakterler arasındaki ilişki düşük oranda kalmıştır (Çizelge 6).

Yaprağın klorofil kapsamını belirlemede kullanılan klorofilmetre (SPAD metre) kullanımının hızlı ve ölçüm anında yaprak yeşilliğine zarar vermeyen bir metot olup en uygun ölçüm zamanı klorofilin en iyi düzeyde olduğu çiçeklenme sonrası dönemdir (Fischer, 2001). Araştırmada bayrak yaprakta klorofil miktarı üç farklı bitki gelişme döneminde ölçülmüş olup kurak koşulların klorofil miktarını azalttığı görülmüştür. Başaklanma öncesi dönemde kuraklığın etkisi düşük olduğu için uygulama konuları ve genotipler arasındaki ilişki önemsiz olmuştur. Başaklanma ve tane dolum dönemlerinde kuraklık uygulamaları ve genotipler arasındaki ilişki çok önemli olmuştur. Ayrıca bitkilerde başaklanma dönemine kadar klorofil miktarında artış olduğu ve daha sonra azalmaya başladığı görülmüştür (Çizelge 4). Kuraklık uygulamalarına göre en yüksek klorofil miktarı başaklanma döneminde yapılan ölçümde belirlenmiştir. Tane dolum döneminde ise genotiplerde klorofil miktarının düştüğü görülmüştür.

Çizelge 4. Araştırmada verim ile uygulama konularında tespit edilen kanopi sıcaklığı ve klorofil miktarı.

\begin{tabular}{cccccccc}
$\begin{array}{c}\text { Uygulama } \\
\text { Konuları }\end{array}$ & \multirow{2}{*}{ VRM } & \multicolumn{3}{c}{ Kanopi sıcaklığı $\left({ }^{\circ} \mathbf{C}\right)$} & \multicolumn{3}{c}{ Klorofil miktarı (SPAD) } \\
\hline KS1 & $549.9 \mathrm{~d}$ & $21.65 \mathrm{a}$ & $28.07 \mathrm{~b}$ & $25.95 \mathrm{~b}$ & $49.47 \mathrm{~b}$ & $50.72 \mathrm{c}$ & $46.08 \mathrm{c}$ \\
KS2 & $563.9 \mathrm{c}$ & $18.53 \mathrm{~d}$ & $21.43 \mathrm{~d}$ & $24.01 \mathrm{c}$ & $50.36 \mathrm{a}$ & $51.98 \mathrm{ab}$ & $47.30 \mathrm{~b}$ \\
$\mathrm{KS} 3$ & $763.8 \mathrm{a}$ & $17.21 \mathrm{e}$ & $19.96 \mathrm{e}$ & $20.11 \mathrm{~d}$ & $50.24 \mathrm{ab}$ & $52.21 \mathrm{a}$ & $51.13 \mathrm{a}$ \\
KS4 & $579.7 \mathrm{~b}$ & $19.36 \mathrm{c}$ & $22.59 \mathrm{c}$ & $26.18 \mathrm{~b}$ & $49.67 \mathrm{ab}$ & $52.34 \mathrm{a}$ & $45.87 \mathrm{c}$ \\
KS5 & $457.8 \mathrm{e}$ & $20.59 \mathrm{~b}$ & $29.21 \mathrm{a}$ & $26.75 \mathrm{a}$ & $49.76 \mathrm{ab}$ & $51.46 \mathrm{~b}$ & $41.72 \mathrm{~d}$ \\
\hline Ortalama & $\mathbf{5 8 3 . 0}$ & $\mathbf{1 9 . 4 7}$ & $\mathbf{2 4 . 2 5}$ & $\mathbf{2 4 . 6 0}$ & $\mathbf{4 9 . 9 1}$ & $\mathbf{5 1 . 7 4}$ & $\mathbf{4 6 . 4 2}$ \\
A.Ö.F & $12.69 * *$ & $0.36^{* *}$ & $0.33^{* *}$ & $0.31^{* *}$ & $0.830 ̈ \mathrm{~d}$ & $0.55^{* *}$ & $0.91^{* *}$ \\
D.K. (\%) & 7.4 & 6.3 & 4.7 & 4.3 & 5.6 & 3.6 & 6.7 \\
\hline
\end{tabular}

Not: **: P<0.01; *: P<0.05; öd: önemli değil, VRM: Tane verimi $\left(\mathrm{kg} \mathrm{da}^{-1}\right)$, CTB: Başaklanma öncesi kanopi sıcaklı̆̆ı, CTH: Başaklanma dönemi kanopi sıcaklığı, CTGF: Tane dolum dönemi kanopi sıcaklığı, CHB: Başaklanma öncesi klorofil, CHH: Başaklanma dönemi klorofil, CHGF: Tane dolum dönemi klorofil.

Genotiplere göre yapılan değerlendirmede en fazla klorofil miktarı başaklanma döneminde 55.23 ile ÖVD2/27-07 çeşidinde ölçülürken, bunu BBVD7 ve Gelibolu çeşitleri takip etmiştir. Genotip uygulama etkileşimine göre klorofil miktarı açısından en yüksek değerler başaklanma öncesi dönemde yapılan ölçümde kuraklık stresi uygulanmayan (KS3) ve geç dönem (KS2) kuraklık uygulamalarında belirlenmiştir. Başaklanma döneminde yapılan ölçümlerde bütün uygulama ve genotiplerde klorofil miktarında artış olmuştur. Başaklanma döneminde doğal uygulama ile destek sulama ile kuraklık stresi uygulanmayan parsellerde belirlenmiştir. Genotiplerde tane dolum döneminde klorofil miktarlarında azalma olurken en az etkilenme kuraklık stresi uygulanmayan parselde olurken en fazla etki tam kuraklık uygulamalarında belirlenmiştir (Çizelge 4 ve 5).

Araştırmada genotipler ve uygulama konuları arasında mumsuluk oranı yönünden farklılık belirlenmiş ve bu faktörler arasında önemli farklılık bulunmuştur. En fazla mumsuluk 8.9 oranı ile BBVD7 hattında belirlenirken, mumsuluğu en düşük Tekirdağ, EBVD24-07 ve Golia çeşitleri olmuştur. Kuraklık uygulamalarına göre yapılan değerlendirmede mumsuluk oranları 3.33 ile 4.40 arasında değişmiş olup, kurak koşulların genotiplerde mumsuluğu artırdığı tespit edilmiştir. Genotip $x$ kuraklık uygulamaları birlikte değerlendirildiğinde mumsuluğun çeşitlerde 
genetik yapıya bağlı olduğu gibi çevre koşullarından da etkilendiği tespit edilmiştir. Genotiplere göre karşılaştırma yapıldığında mumsuluk ile tane verimi arasında olumlu ilişki tespit edilirken (Şekil 3), uygulama konularına göre yapılan karşılaştırmada kurak koşullarda mumsuluğun artması dolayısı ile kuraklık ile mumsuluk arasında olumsuz ilişki (Şekil 2) belirlenmiştir. Bu sonuç mumsuluk oranı için genotip ve çevre koşullarının birlikte etki ettiği, mumsuluk yönünden genotip ve çevre koşullarının birlikte değerlendirilmesi sonucuna ulaşılmıştır. Mumsu yapıya sahip çeşitlerin, mumsuzlara göre daha fazla biyolojik ve tane verimine sahip olduğu (Dakheel ve Makdis 1991), kurağa dayanıklı bitkiler, kurak koşullara uyum sağlamak için yaprak mumsuluk oranını artırması gibi bazı fizyolojik özellikleri içerdiği (Kalaycı ve ark., 1998), kuraklığa toleransta bitkilerde yaprak mumsuluğu değerlendirilmesi gereken önemli özelliklerden (Dencic ve ark., 2000) olduğunu belirten araştırmacıların bulgularını bu çalışmada da görmek mümkün olmuştur.

Uygulama konularına göre tane verimi ile başaklanma gün sayısı, olgunlaşma gün sayısı, tane dolum süresi arasında pozitif ilişki saptanmıştır (Şekil 2). Genotiplerde olgunlaşma süresinin uzaması dolayısı ile tane dolum süresi de uzamış ve bu durum verime olumlu şekilde yansımıştır.

Çizelge 5. Araştırmada genotiplerde incelenen karakterlere göre tespit edilen ortalama değerler.

\begin{tabular}{|c|c|c|c|c|c|c|c|c|c|}
\hline Ç.No & Genotipler & VRM & CTB & CTH & CTGF & CHB & $\mathrm{CHH}$ & CHGF & MUM \\
\hline 1 & Kate A-1 & $\begin{array}{c}631.5 \\
b c\end{array}$ & $18.79 \mathrm{~g}$ & $23.78 \mathrm{e}$ & $22.78 \mathrm{~h}$ & $50.32 d$ & $\begin{array}{c}52.53 \\
\text { de }\end{array}$ & $\begin{array}{c}47.56 \\
\text { bcd }\end{array}$ & $6.1 b$ \\
\hline 2 & Gelibolu & $\begin{array}{l}613.0 \\
\text { cde }\end{array}$ & $19.55 \mathrm{bcd}$ & 24.12 cde & $23.46 \mathrm{~g}$ & $50.80 \mathrm{~cd}$ & $\begin{array}{c}53.62 \\
b c\end{array}$ & $\begin{array}{c}47.69 \\
\text { bc }\end{array}$ & $3.7 \mathrm{~d}$ \\
\hline 3 & Pehlivan & $587.7 \mathrm{fg}$ & $19.35 \mathrm{cde}$ & 24.14 cde & $\begin{array}{c}24.45 \\
\text { def }\end{array}$ & $48.35 \mathrm{fg}$ & $49.16 \mathrm{jk}$ & $43.39 f$ & $5.9 \mathrm{~b}$ \\
\hline 4 & Tekirdağ & $\begin{array}{c}594.5 \\
\text { efg }\end{array}$ & $19.91 a b$ & $24.91 \mathrm{a}$ & $25.34 \mathrm{~b}$ & 49.83 def & $\begin{array}{c}52.59 \\
\text { cde }\end{array}$ & $46.45 d$ & ו I.0 \\
\hline 5 & Selimiye & $\begin{array}{c}608.9 \\
\text { def }\end{array}$ & $19.57 \mathrm{bcd}$ & $24.30 \mathrm{bcd}$ & $\begin{array}{c}24.10 \\
\text { ef }\end{array}$ & $47.65 \mathrm{~g}$ & j & $44.68 \mathrm{e}$ & $5.0 \mathrm{c}$ \\
\hline 6 & Aldane & ا I 551.1 & $19.24 \mathrm{def}$ & $24.47 a b c$ & $\begin{array}{c}24.50 \\
\text { de }\end{array}$ & $47.29 \mathrm{~g}$ & $51.39 \mathrm{fg}$ & $44.79 \mathrm{e}$ & $5.1 \mathrm{c}$ \\
\hline 7 & Flamura-85 & $518.9 \mathrm{j}$ & $19.74 a b$ & $24.38 \mathrm{bcd}$ & $25.34 \mathrm{~b}$ & $51.95 \mathrm{abc}$ & $\begin{array}{c}53.01 \\
\text { bcd }\end{array}$ & $48.03 \mathrm{~b}$ & $2.8 \mathrm{e}$ \\
\hline 8 & Golia & $\begin{array}{c}610.4 \\
\text { cde }\end{array}$ & $20.08 \mathrm{a}$ & $24.70 \mathrm{ab}$ & $26.19 \mathrm{a}$ & $48.08 \mathrm{~g}$ & $50.24 \mathrm{hı}$ & $40.18 \mathrm{~g}$ & $1.2 \mathrm{hl}$ \\
\hline 9 & BBVD7 & $\begin{array}{c}651.0 \\
a b\end{array}$ & $18.94 \mathrm{fg}$ & $24.20 \mathrm{~b}-\mathrm{e}$ & $\begin{array}{c}23.95 \\
\mathrm{fg}\end{array}$ & $50.90 \mathrm{bcd}$ & $53.91 b$ & $\begin{array}{c}47.25 \\
\text { bcd }\end{array}$ & $8.9 \mathrm{a}$ \\
\hline 10 & Bereket & $658.3 \mathrm{a}$ & 19.04 efg & $23.92 \mathrm{de}$ & $\begin{array}{c}24.22 \\
\text { ef }\end{array}$ & $49.92 \mathrm{de}$ & $\begin{array}{c}51.79 \\
\text { ef }\end{array}$ & $\begin{array}{c}46.67 \\
\mathrm{~cd}\end{array}$ & $5.1 \mathrm{c}$ \\
\hline 11 & ÖVD26-07 & $\begin{array}{l}579.1 \\
\text { gh }\end{array}$ & $19.71 \mathrm{abc}$ & 24.43 a-d & $25.45 \mathrm{~b}$ & $48.16 \mathrm{~g}$ & $\begin{array}{c}50.75 \\
\text { ghı }\end{array}$ & $\begin{array}{c}44.43 \\
\text { ef }\end{array}$ & $2.0 \mathrm{fg}$ \\
\hline 12 & $\begin{array}{l}\text { ÖVD2/21- } \\
07\end{array}$ & $563.0 \mathrm{hl}$ & $19.31 \mathrm{def}$ & $23.94 \mathrm{de}$ & $25.31 b$ & $51.07 \mathrm{bcd}$ & $\begin{array}{c}51.16 \\
\mathrm{fgh}\end{array}$ & $\begin{array}{c}47.68 \\
\text { bc }\end{array}$ & $1.5 \mathrm{gh}$ \\
\hline 13 & $\begin{array}{l}\text { ÖVD2/27- } \\
07\end{array}$ & $\begin{array}{c}617.8 \\
\mathrm{~cd}\end{array}$ & 19.27 def & 24.00 cde & $\begin{array}{c}25.01 \\
b c\end{array}$ & $53.39 \mathrm{a}$ & $55.23 \mathrm{a}$ & $49.62 \mathrm{a}$ & $6.3 \mathrm{~b}$ \\
\hline 14 & EBVD24-07 & $\begin{array}{c}577.4 \\
\text { gh }\end{array}$ & $19.59 \mathrm{bcd}$ & 24.02 cde & $\begin{array}{c}24.79 \\
\mathrm{~cd}\end{array}$ & $52.39 a b$ & $\begin{array}{c}52.01 \\
\text { def }\end{array}$ & $50.60 a$ & $1.1 \mathrm{hl}$ \\
\hline 15 & BBVD21-07 & $383.0 \mathrm{k}$ & $19.92 a b$ & $24.48 a b c$ & $\begin{array}{c}24.09 \\
\text { ef }\end{array}$ & 48.40 efg & $48.80 \mathrm{k}$ & $\begin{array}{c}47.26 \\
\text { bcd }\end{array}$ & $2.1 \mathrm{f}$ \\
\hline & Ortalama & 583.0 & 19.47 & 24.25 & 24.60 & 49.91 & 51.74 & 46.42 & 3.85 \\
\hline & A.Ö.F (0.05) & 21.94 & 0.38 & 0.52 & 0.50 & 1.55 & 1.03 & 1.15 & 0.50 \\
\hline & $\mathrm{F}$ & $* *$ & $* *$ & $* *$ & $* *$ & öd & $* *$ & $* *$ & $* *$ \\
\hline
\end{tabular}

Not: ${ }^{* *}: \mathrm{P}<0.01 ;{ }^{*}: \mathrm{P}<0.05$; öd: önemli değil, VRM: Tane verimi, CTB: Başaklanma öncesi kanopi sıcaklığı, CTH: Başaklanma dönemi kanopi sıcaklığı, CTGF: Tane dolum dönemi kanopi sıcaklığı, CHB: Başaklanma öncesi klorofil, $\mathrm{CHH}$ : Başaklanma dönemi klorofil, CHGF: Tane dolum dönemi klorofil, MUM: Mumsuluk (1-9). 


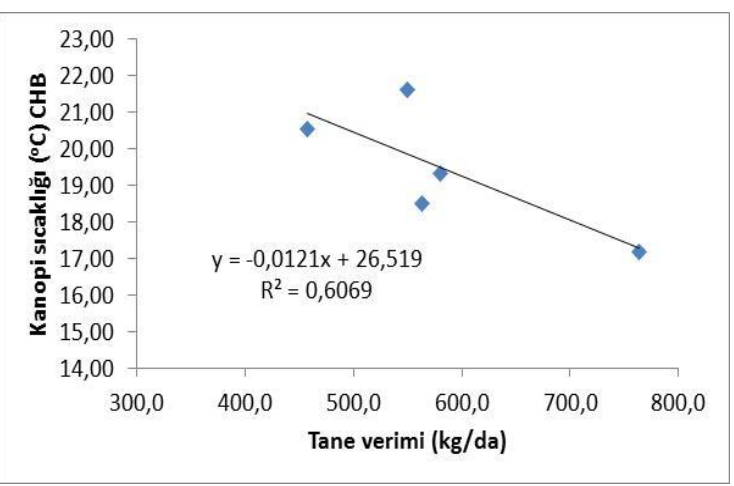

Tane verimi ve başaklanma öncesi kanopi sıcaklığı

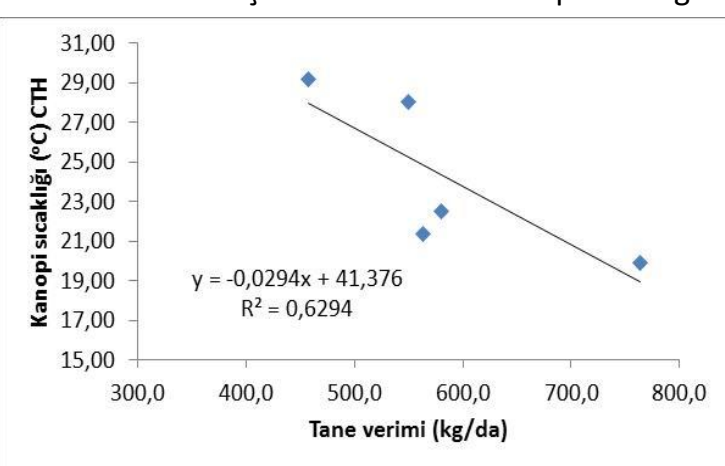

Tane verimi ve başaklanma dönemi kanopi sıcaklığı

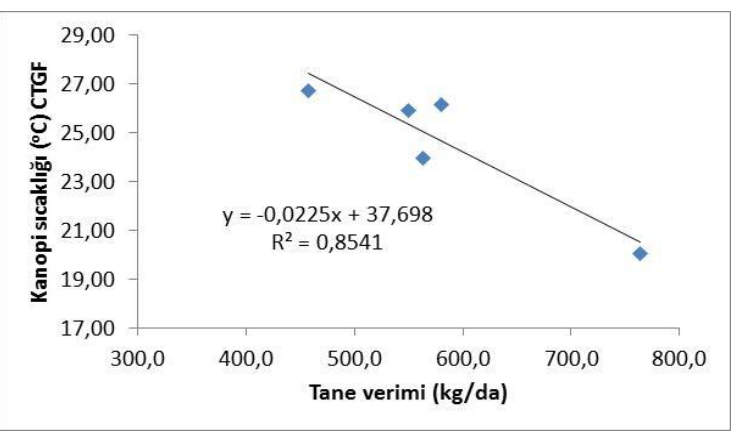

Tane verimi ve tane dolum dönemi kanopi sıcaklığı

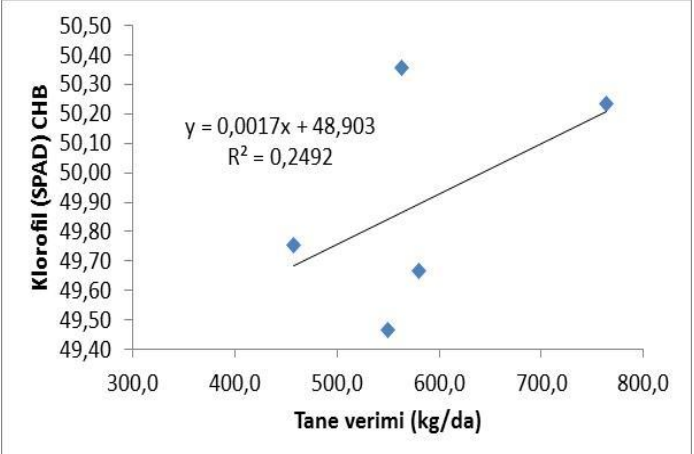

Tane verimi ve başaklanma öncesi klorofil miktarı

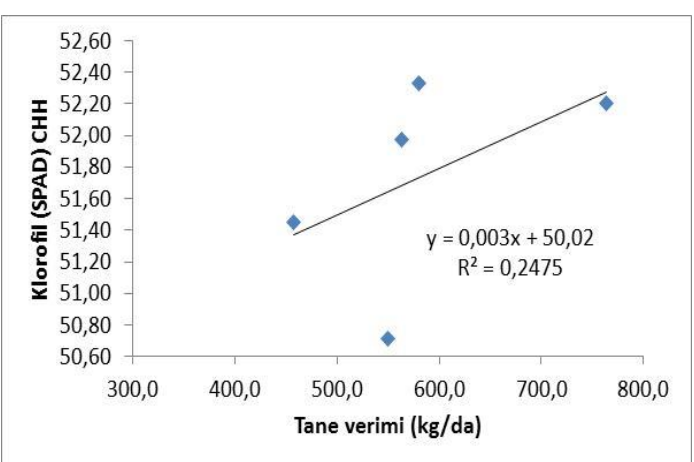

Tane verimi ve başaklanma dönemi klorofil miktarı

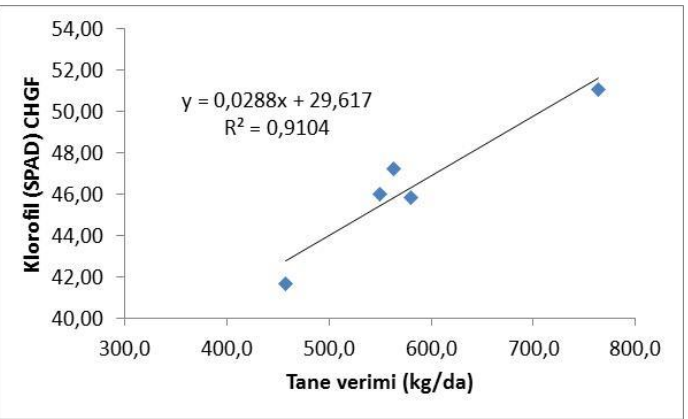

Tane verimi ve tane dolum dönemi klorofil miktarı

Şekil 1. Farklı bitki gelişme dönemlerinde kuraklık uygulamalarında verim ile klorofil miktarı (SPAD) ve kanopi sıcaklığı $\left({ }^{\circ} \mathrm{C}\right)$ arasında belirlenen ikili ilişkiler.

Araştırmada genotiplerde beş farklı kuraklık seviyesine göre mumsuluk oranları belirlenmiş ve tespit edilen bu mumsuluk oranları tane verimi ile ikili karşılaştırması yapışmıştır (Şekil 3). Tane verimi ile mumsuluk oranı arasında en yüksek pozitif ilişki $(r=0.322)$ kuraklık stresi uygulanmayan koşullarda belirlenirken, tane verimi ile başaklanma döneminden fizyolojik olum dönemine kadar kuraklığın uygulandığı koşullarda da olumlu $(r=0.277)$ ilişki saptanmıştır. Çalışmada doğal koşullarda ve tam kuraklık uygulamalarında yapılan ikili karşılaştırmada tane verimi ile mumsuluk arasında olumlu ilişki bulunmuştur (Şekil 3). Bu sonuç farklı çevre koşulları altında yakın ve benzeri ilişki belirlenmesi tane verimi yönünden mumsuluğun diğer fizyolojik ve agronomik karakterlere göre değerlendirilmesi gereken bir parametre olduğu yorumu yapılabilir.

Farklı seviyede kuraklık ile farklı bitki gelişme dönemlerinde belirlenen verim, kanopi sıcaklığı ve klorofil miktarı ile bazı fizyolojik karakterler arasındaki korelasyon katsayıları Çizelge 4'te verilmiştir. Tane verimi ile kanopi sıcaklığı arasında ilişki başaklanma öncesi dönemde yapılan ölçümde $r=-0.779$, başaklanma döneminden yapılan ölçümlerde $r=-0.793$ ve tane dolum döneminde $r=$ -0.924* olarak belirlenmiştir. Bu sonuç farklı çevre koşulları altında yüksek verim potansiyeline sahip genotiplerin belirlenmesi için bitki gelişiminin daha geç döneminde yapılması durumunda daha etkin bir seleksiyon yapılabileceği sonucuna varılmıştır. 


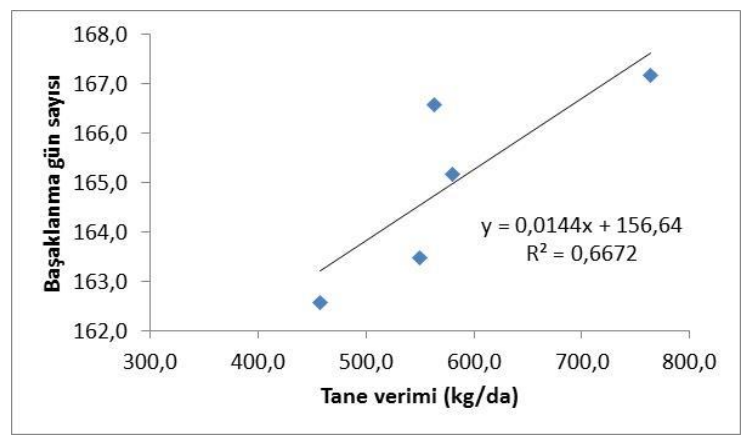

Tane verimi ve başaklanma gün sayısı

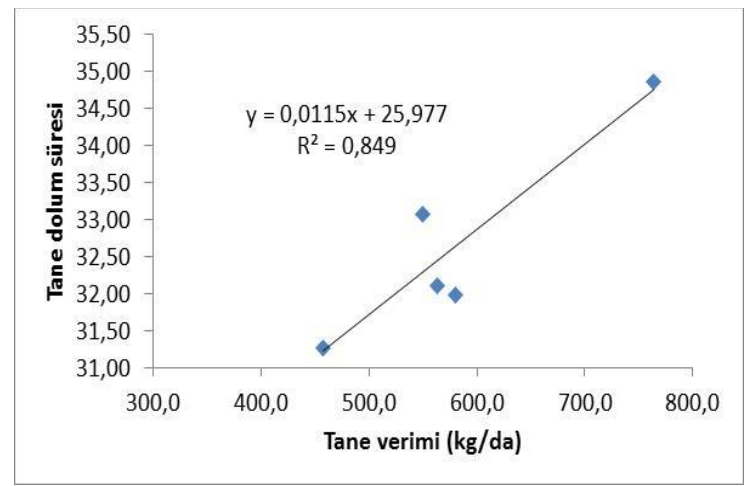

Tane verimi ve tane dolum süresi

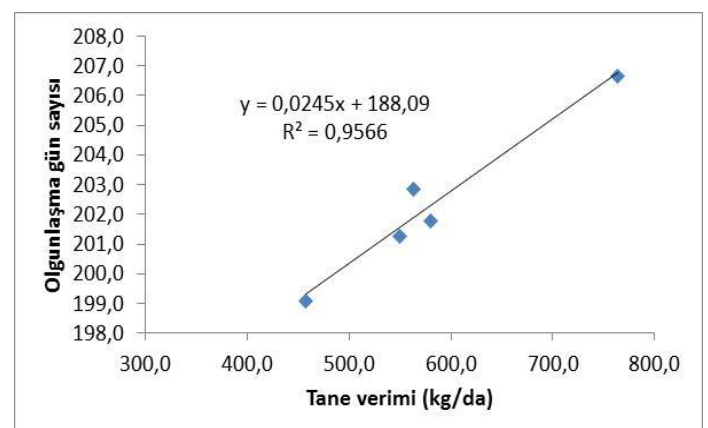

Tane verimi ve olgunlaşma gün sayısı

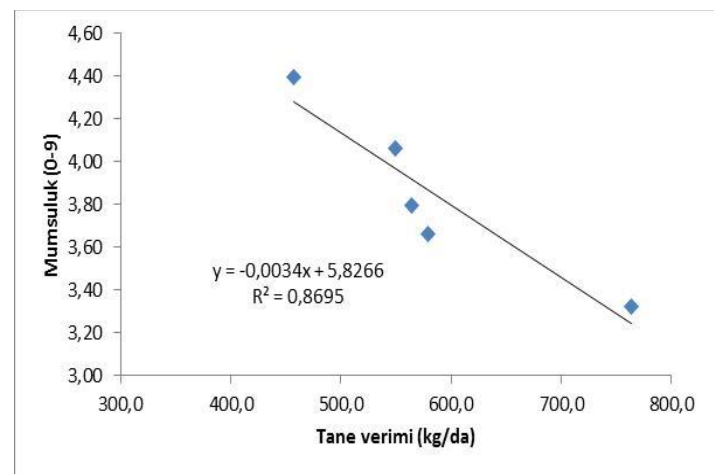

Tane verimi ve mumsuluk oranı

Şekil 2. Farklı dönem kuraklık uygulanan parsellerde verim ile klorofil miktarı (SPAD) ve kanopi sıcaklığı $\left({ }^{\circ} \mathrm{C}\right)$ arasında belirlenen ikili ilişkiler.

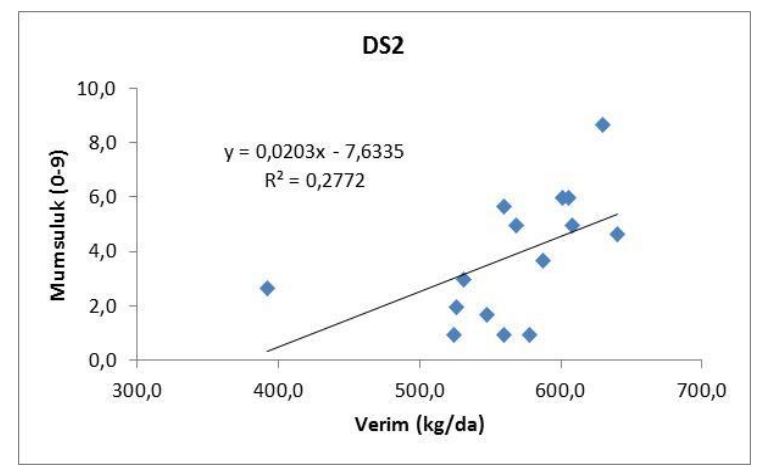

Tane verimi ve KS2 dönemi mumsuluk

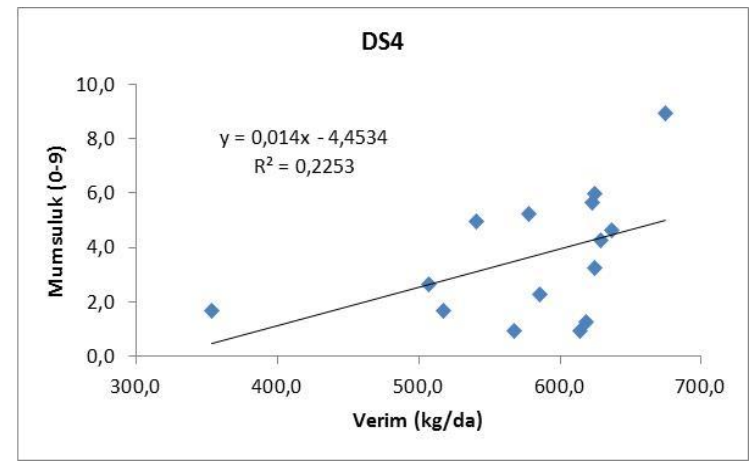

Tane verimi ve KS4 dönemi mumsuluk

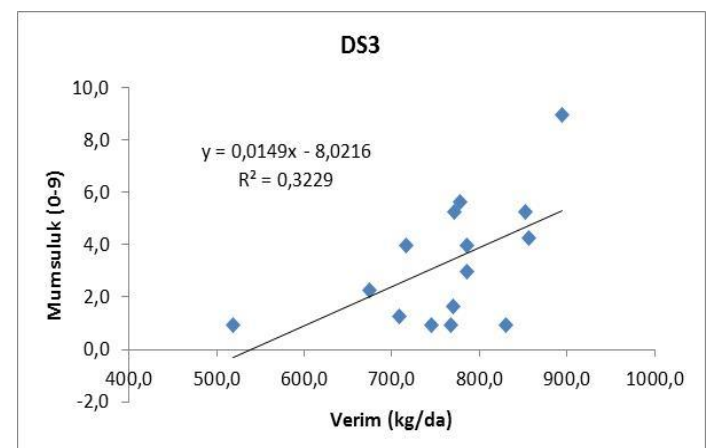

Tane verimi ve KS3 dönemi mumsuluk

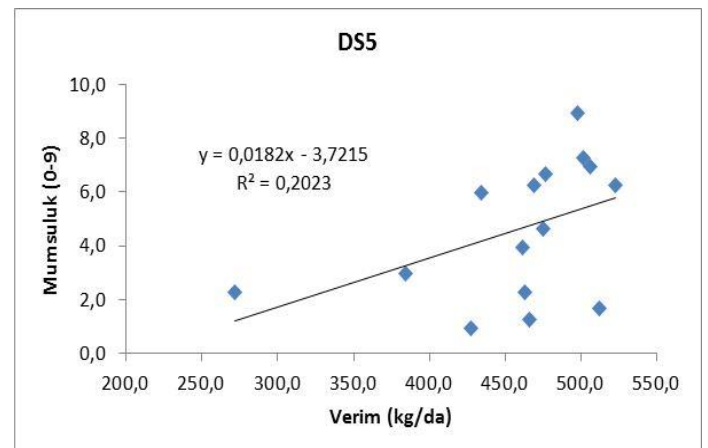

Tane verimi ve KS5 dönemi mumsuluk

Şekil 3. Farklı dönem kuraklık uygulanan parsellerde genotiplere göre verim ile mumsuluk oranı (1-9) arasında belirlenen ikili ilişkiler.

İncelenen parametreler arasındaki korelasyon ve parametrelere göre yıl, genotip ve uygulama konuları arasındaki etkileşim Pearson korelasyon analizi ile belirlenmiştir. Kuraklık stresi klorofil miktarını ölçümü yapılan üç bitki gelişme döneminde de olumsuz yönde etkileyerek 
düşürdüğü gibi başaklanma dönemindeki kuraklığın daha fazla etkilediği belirlenmiştir. En yüksek klorofil miktarı kuraklık stresi uygulanmayan koşullarda belirlenmesi klorofil kapsamı ile tane verimi arasında olumlu yönde ilişki olduğu sonucunu doğrulamıştır. Tane verimi ile bayrak yaprak klorofil içeriği arasında ilişki başaklanma öncesi $r=0.499$, başaklanma dönemi $r=0.498$ ve tane dolum dönemi $r=0.954$ * olarak belirlenmiştir. Farklı çevre koşulları altında tane verimi ile klorofil kapsamı arasında sapa kalkma döneminden tane dolum dönemine kadar olumlu yönde sürekli artan bir ilişki saptanması yüksek verim potansiyeline sahip genotiplerin belirlenmesinde geç dönemde yapılacak klorofil ölçümünün daha etkili olacağı sonucuna ulaşılmıştır. Başaklanma gün sayısı ile kanopi sıcaklığı arasında başaklanma öncesi dönemde $r=-0.915^{*}$, başaklanma döneminden $r=-$ $0.983^{* *}$ ve tane dolum döneminde $r=-0.829$ olarak belirlenmiştir. Benzeri olumsuz ilişki olgunlaşma gün sayısı ve tane dolum süresi ile kanopi sıcaklığı arasında da tespit edilmiştir. Erkenci çeşitlerde kanopi sıcaklığının daha yüksek olduğu verim ile ikili karşılaştırmada da görülmüş olup çok erkenci çeşitlerin hem verim hem kanopi sıcaklığı arasında uygun olmadığı sonucuna ulaşılmıştır. Tane verimi ile başaklanma gün sayısı arasında $r=0.817$, olgunlaşma gün sayısı $r=0.978^{* *}$ ve tane dolum süresi $r=0.921 *$ arasında yüksek oranda olumlu ilişki belirlenmesi fizyolojik olum süresi ve tane dolum süresinin uzamasına bağlı olarak genotiplerde tane veriminin de yükseldiği görülmüştür (Çizelge 6).

Çizelge 6. Farklı kuraklık uygulamasında belirlenen verim, kanopi sıcaklığı ve klorofil miktarı ile bazı fizyolojik karakterler arasındaki korelasyon katsayıları.

\begin{tabular}{|c|c|c|c|c|c|c|c|c|c|c|}
\hline Karakter & VRM & CTB & CTH & CTGF & CHB & $\mathrm{CHH}$ & CHGF & BGS & OGS & TDS \\
\hline CTB & -0.779 & & & & & & & & & \\
\hline СТH & -0.793 & $0.922 *$ & & & & & & & & \\
\hline CTGF & $-0.924^{*}$ & 0.844 & 0.761 & & & & & & & \\
\hline $\mathrm{CHB}$ & 0.499 & -0.857 & -0.746 & -0.733 & & & & & & \\
\hline $\mathrm{CHH}$ & 0.498 & -0.847 & -0.819 & -0.456 & 0.602 & & & & & \\
\hline $\mathrm{CHGF}$ & $0.954 *$ & -0.745 & -0.832 & $-0.905^{*}$ & 0.570 & 0.420 & & & & \\
\hline BGS & 0.817 & $-0.915^{*}$ & $-0.983 * *$ & -0.829 & 0.805 & 0.718 & $0.885^{*}$ & & & \\
\hline OGS & $0.978 * *$ & -0.838 & -0.854 & $-0.961 * *$ & 0.648 & 0.517 & $0.980 * *$ & 0.898* & & \\
\hline TDS & $0.921^{*}$ & -0.523 & -0.526 & -0.866 & 0.313 & 0.126 & 0.889* & 0.599 & $0.885^{*}$ & \\
\hline MUM & $-0.932^{*}$ & 0.833 & $0.932 *$ & 0.810 & -0.533 & -0.692 & $-0.925 *$ & $-0.914 *$ & $-0.930 *$ & -0.742 \\
\hline
\end{tabular}

Not: ${ }^{* *}: \mathrm{P}<0.01 ;{ }^{*}: \mathrm{P}<0.05$; VRM: Tane verimi $\left(\mathrm{kg} \mathrm{da}^{-1}\right)$; CTB: Başaklanma öncesi kanopi sıcaklığı $\left({ }^{\circ} \mathrm{C}\right), \mathrm{CTH}$ : Başaklanma dönemi kanopi sıcaklığı $\left({ }^{\circ} \mathrm{C}\right), \mathrm{CTGF}$ : Tane dolum dönemi kanopi sıcaklığı $\left({ }^{\circ} \mathrm{C}\right), \mathrm{CHB}$ : Gebeleşme dönemi klorofil, CHH: Başaklanma dönemi klorofil, CHGF: Tane dolum dönemi klorofil, BGS: Başaklanma gün sayıSI, OGS: Olgunlaşma gün sayısı, TDS: Tane dolum süresi, MUM: Mumsuluk (1-9).

\section{Sonuç ve Öneriler}

Sonuç olarak araştırmada verim, kanopi sıcaklığı ve klorofil miktarına göre genotipler ve uygulama konuları arasında önemli farklılıklar olmuş ve kuraklık uygulamaları bitki örtüsü sıcaklığını artırırken, klorofil miktarını azaltmıştır. Kuraklık stresi klorofil miktarını ölçümü yapılan üç bitki gelişme döneminde de düşürdüğü gibi başaklanma döneminde kuraklık stresinin etkisinin daha fazla olduğu belirlenmiştir. Farklı çevre koşulları altında tane verimi ile klorofil kapsamı arasında sapa kalkma döneminden tane dolum dönemine kadar olumlu yönde sürekli artan bir ilişki saptanması yüksek verim potansiyeline sahip genotiplerin belirlenmesinde geç dönemde yapılacak klorofil ölçümünün daha etkili olacağı sonucuna ulaşılmıştır. Genotiplere göre en düşük bitki örtüsü sıcaklığı Kate A-1 ve en yüksek sıcaklık Golia çeşidinde ölçülmüştür. Düşük kanopi sıcaklığına sahip genotipler ve uygulamalarda daha yüksek verim elde edilmiştir. Başaklanma öncesinde kanopi sıcaklığı ile tane verimi arasındaki ilişki düşük oranda iken tane dolum döneminde bu ilişkinin daha yüksek oranlara ulaştığı görülmüştür. Bu sonuç yüksek verim potansiyeline sahip genotiplerin belirlenmesinde geç dönemde yapılacak kanopi sıcaklığı ölçümünün seleksiyonda daha etkili olacağını göstermiştir. Genotiplerde yapraklarda mumsuluk oranının artışı kanopi sıcaklığını düşürmüş olup bu sonuç mumsuz ve açık yaprak rengine sahip olan genotiplerin kanopi sıcaklığı ile bu karakterlerin ilişkisini göstermiştir. Bu sonuç mumsuluk oranı için genotip ve çevre koşullarının birlikte etki ettiği, mumsuluk yönünden genotip ve çevre koşullarının birlikte değerlendirilmesi sonucuna ulaşılmıştır. Ayrıca genotiplerde fizyolojik olum süresi ve tane dolum süresinin uzamasına bağlı olarak tane veriminin yükseldiği belirlenmiştir.

a: Doktora tezinden derlenmiştir.

\section{Kaynaklar}

Amani, I., Fischer, R.A. and Reynolds, M.P. 1996. Evaluation of canopy temperature as a 
screening tool for heat tolerance in spring wheat. Journal of Agronomy and Crop Science 176: 119-129.

Anonim, 2014. Trakya Tarımsal Araştırma Enstitüsü, Proje Faaliyet Raporları, Edirne.

Araus, J.L. 1996. Integrati ve physiological criteria associated with yield potential. In: Reynolds, MP., Rajaram, S., Mc Nab, A. (Eds.). Increasing yield potential in wheat: breaking the barriers. CIMMYT, Mexico, D.F.

Ayeneh, A., Van Ginkel, M., Reynolds, M.P., Ammar, K. 2002. Comparison of leaf, spike, peduncle and canopy temperature depression in wheat under heat stress. Field Crops Research 79 (2-3), 173-184.

Babar, M.A., Reynolds, M.P., van Ginkel, M., Klatt, A.R., Raun, W.R., Stone M.L. 2006a. Spectral reflectance to estimate genetic variation for in-season biomass, leaf chlorophyll and canopy temperature in wheat. Crop Science 46, 1046-1057.

Babar, M.A., Reynolds, M.P., Van Ginkel, M., Klatt, A.R., Raun, W.R., Stone, M.L. 2006b. Spectral reflectance indices as potential indirect selection criteria for wheat yield under irrigation. Crop Sci. 46: 578-588.

Blum, A., Shpiler, L., Golan, G. and Mayer, J. 1989. Yield Stability and Canopy Temperature of Wheat Genotypes under Drought-Stress. Field Crop Research, 22: 289-296.

Blum, A. 2000. Mitigation of Drought Stress by Crop Management. Plant Stres.com, http://www.plantstress.com/articles/droug ht_m/.

Clarke, J. M., McCaig, T.N. 1982. Excised-leaf water retention capability as an indicator of drought resistance of Triticum genotypes. Canadian Journal of Plant Science, 62(3): 571-578.

Dakheel, A., Makdis, F. 1991. The Role of Glaucousness as a Selection Criterion for Drought Tolerance in Durum Wheat. Cereal Improvement Program. Annual Report, 120121. ICARDA, Aleppo.

Dencic, S., Kastori, R., Kobiljski, B., Duggan, B. 2000. Evaluation of grain yield and its components in wheat cultivars and landraces under near optimal and drought conditions. Euphytica, 113: 43-52.

Diaz, R. A., Mathias, A. D., and Hanks, R. J. 1983. Evapotranspiration and yield estimation of spring wheat from canopy temperature. Agronomy Journal, 75: 805-810.

Fischer, R.A. 2001. Selektion Traits for Improving Yield Potantial. Application of Physiology in Wheat Breeding. Chapter-13, pp. 148-159.
International Maize and Wheat Improvement Center, CIMMYT. Mexico.

Fischer, R.A. 2007. Understanding the physiological basis of yield potential in wheat. Journal of Agricultural Science 145: 99-113.

Fuchs, M. 1990. Infrared measurement of canopy temperature and detection of plant water stress. Theoretical and Applied Climatology 42(4): 253-261.

Gomez, K.A. and Gomez, A.A. 1984. Statistical Procedures for Agricultural Research. $2^{\text {nd }}$ Ed. John Willey and Sons, Inc. New York. 641.

Idso, S. B., Reginate, R. J., Hatfield, J. L., and Pinter, P. J. Jr. 1981. Measuring yield reducing plant water potential depression in wheat by infrared thermometry. Irrigation Science 2: 205-212.

Jefferson, P.G., Johnson, D.A., and Asay, K. H. 1989. Epicuticular wax production, water status and leaf temperature in Triticeae range grasses of contrasting visible glaucousness. Canadian Journal of Plant Science, 69(2): 513-519.

Kalaycı, M., Özbek, V., Çekiç, C., Ekiz, H., Keser, M., Altay, F. 1998. Orta Anadolu Koşullarında Kurağa Dayanıklı Buğday Genotiplerinin Belirlenmesi ve Morfolojik ve Fizyolojik Parametrelerin Geliştirilmesi. TÜBITAK Araştırma Projesi Kesin Raporu. Anadolu Tarımsal Araştırma Enstitüsü, Eskişehir.

Kalaycı, M. 2005. Örneklerle Jump Kullanımı ve Tarımsal Araştırma için Varyans Analiz Modelleri, Anadolu Tarımsal Araştırma Enst, Müd, Yayınları, Yayın No: 21, Eskişehir.

Lopes, M.S. and Reynolds, M.P. 2010 Partitioning of assimilates to deeper roots is associated with cooler canopies and increased yield under drought in wheat. Functional Plant Biology 37(2): 147-156.

Lopes, M.S. and Reynolds, M.P. 2012. Stay-green in spring wheat can be determined by spectral reflectance measurements (normalized difference vegetation index) independently from phenology. Journal of Experimental Botany (in review).

Loss, S.P. and Siddique, K.H.M. 1994. Morphological and physiological traits associated with wheat yield increases in Mediterranean environments. Adv. Agron. 52: 229-276.

Merah, O., Deleens, E., Souyris, I., Monneveux, P. 2000. Effect of glaucousness on carbon isotope discrimination and grain yield in durum wheat. Journal of Agronomy and Crop Science, 185(4): 259-265.

Öztürk i, Kahraman T, Avci R, Girgin V.Ç, Şili Ş, Kılıç T.H, Tülek A, Tuna B. 2018. Effect of the Rainfall and Humidity at Various Growth 
Stage on Yield and Quality in Bread Wheat (Triticum aestivum L.) Cultivars. Agriculture \& Food. Journal of International Scientific Publications. Volume 6, p: 26-36. (ISSN 13148591).

Pask, A.J.D., J. Pietragalla, D.M. Mullan, M.P. Reynolds, (Eds.). 2012. Physiological Breeding II: A Field Guide to Wheat Phenotyping. Mexico, D.F.: CIMMYT.

Reynolds, M.P., Balota, M., Delgado, M.I.B., Amani, I., Fischer, R.A. 1994. Physiological and morphological traids associated with spring wheat yield under hot irrigated conditions. Australian Journal Plant Physiology, 21: 717730.

Reynolds, M., Skovmand, B., Trethowan, R. 2000. Evaluating a conceptual model for drought tolerance. A Strategic Planning Workshop, 21-25 June 1999. CIMMYT, Mexico, pp.4953.

Reynolds, M.P., Nagarajan, S., Razzaque, M.A., Ageeb, O.A.A. 2001. Heat Tolerance. Applicationof Physioloji in Wheat Breeding, Chapter 10, p.124-135. International Maize and Wheat Improvement Center, CIMMYT. Mexico.

Reynolds, M.P., Ortiz, R. 2010. Adapting crops to climate change: a summary. In: Reynolds MP (ed), Climate change and crop production. CAB international, pp. 1-8.

Reynolds, M.P., Ortiz-Monasterio, J.I., McNab, A (eds.). 2001. Application of Physiology in Wheat Breeding. Mexico, D.F.: CIMMYT.

Richards, R.A., Rawson, H.M., Johnson, D. A. 1986. Glaucousness in wheat: its development and effect on water-use efficiency, gas exchange and photosynthetic tissue temperatures. Functional Plant Biology, 13(4): 465-473.

Shimazaki, Y., Ookawa, T., Hirazawa, T. 2005. The root tip and accelerating region supress elongation of the decelerating region without any effects on cell turgor in primary roots of maize under water stress. Plant Physiol. 139: 458-465.

Zadoks, J.C., Chang, T.T., Konzak, C.F. 1974. A decimal code for growth stages of cereals. Weed Res. 14: 415-421. 